\title{
Radical reconciliation: The TRC should have allowed Zacchaeus to testify?
}

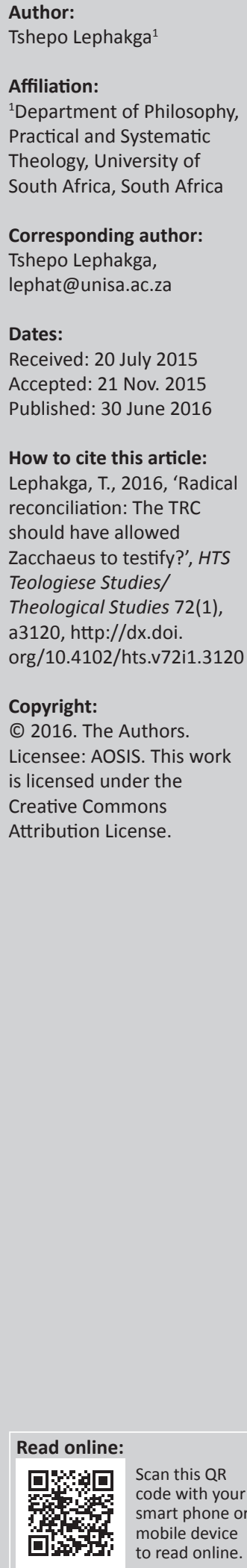

This article seeks to point out that, the inclusion of a theological term - that is 'reconciliation' (at the request of F.W. de Klerk on behalf of the National Party) to what was supposed to be the 'Truth Commission' (Boesak \& DeYoung 2012; Stevens Franchi \& Swart 2006) - was for the purpose of taming the work of this commission and using reconciliation to merely reach some political accommodation which did not address the critical questions of justice, equality, and dignity which are prominent in the biblical understanding of reconciliation (Boesak 2008; Boesak \& DeYoung 2012:1; Lephakga 2015; Terreblanche 2002). However, it is important to point out that, the problem was not the theological word - that is 'reconciliation'- but the understanding and interpretation of it in South Africa. This is because previously in South Africa the Bible was made a servant to ideology (Lephakga 2012, 2013; Moodie 1975; Serfontein 1982) and thus domesticated for the purposes of subjection and control (Boesak \& DeYoung 2012). As such, this article contends that, the call for the inclusion of 'reconciliation' within the 'truth commission' was not to allow reconciliation to confront the country with the demands of the gospel but to blunt the process of radical change (Boesak \& DeYoung 2012). Therefore, this article will point out that the shortcomings of the South African Truth and Reconciliation Commission (TRC) need to be understood against the following events which occurred between the period 1989 to 1995: (1) the fall of the Soviet Union (Cronin 1994:2-6); (2) the National Party's (NP) and South African business sector's interest in negotiations with the African National Congress (ANC) (Cronin 1994:2-6; Mkhondo 1993:3-43; Terreblanche 2002:51-124); (3) the elite compromise (Terreblanche 2002:51-124); and the sudden passing of the Promotion of National Unity and Reconciliation Act, no 34 of 1995 (TRC, Vol. 1998). This paper will use the story of Zacchaeus to contend that the TRC should have allowed Zacchaeus (so to speak) to testify in order to hear from him what reconciliation means (Boesak \& DeYoung 2012:64). This is because, on the one hand, this commission made an extraordinary move when it appointed a Christian priest (which is unusual in the history of these commissions - Boesak \& DeYoung 2012; Lephakga 2015; Stevens et al. 2006; Terreblanche 2002), namely Desmond Tutu (Boesak 2008; Boesak \& DeYoung 2012; Lephakga 2015; Stevens et al. 2006; Terreblanche 2002), as its chair and on the other hand, the chair - that is Desmond Tutu - made another extraordinary move when he Christianised the whole process of this commission when he opened most of the sessions with prayer, invoking the name of Jesus Christ (for forgiveness), and inviting the Holy Spirit to guide the proceedings of this commission (Boesak \& DeYoung 2012; Lephakga 2015). However this commission invoked the name of Jesus Christ and the Holy Spirit for the purpose of forgiveness but ignored what Jesus Christ is asking in terms of justice which is clearly illustrated in the Story of Zacchaeus (Boesak \& DeYoung 2012; Lephakga 2015). Therefore, this article will argue that if Jesus Christ and the Holy Spirit were invited into the processes of this commission, then Zacchaeus too should have been allowed to testify - so to say.

\section{Introduction}

Although significant attention has focused on the South African Truth and Reconciliation Commission (TRC) and its successes and/or failures, the actual concept of truth commissions can be traced to as early as the 1970s in Uganda (Lephakga 2015; Mamdani in Amadiume \& Abdullahi 2000; Stevens et al. 2006:296; Terreblanche 2002). The establishment of truth commissions gained prominence in Latin America in the 1980s (Stevens et al. 2006:296; Terreblanche 2002). This point is made to emphasise that as a result of the historical and ideological influences of the truth commission in Uganda in 1974 (Quinn 2003), the National Commission on the Disappeared in Argentina in 1983 (Crenzel 2008), the National Commission for Truth and Reconciliation in Chile in 1991 (Ensalaco 1994), and the Commission of Inquiry in Chad in 1992 (Stevens et al. 2006:296-297; Terreblanche 2002), the TRC obscured what was distinctive about apartheid in South Africa (Lephakga 2015; Mamdani in Amadiume \& Abdullahi 2000:179; Terreblanche 2002). This claim is 
based on the three key limitations in the TRC's report as identified by Mamdani (2002:32-59) in his famous work on the TRC titled Amnesty or Impunity? A Preliminary Critique of the Truth and Reconciliation Commission of South Africa. Firstly, Mamdani points out that the TRC individualised the victims of apartheid despite the commission's acknowledgement that apartheid is a crime against humanity which targeted entire communities for ethnic and racial policing and cleansing (Lephakga 2015; Mamdani 2002:33; Terreblanche 2002). Secondly, Mamdani points out that this Commission, by focusing on individuals and obscuring the victimisation of communities, was unable to highlight the bifurcated nature of apartheid as a form of power that governed natives differently from non-natives (Lephakga 2015; Mamdani 1996, 2002:34; Terreblanche 2002). Finally, Mamdani points out that this Commission extended impunity to most perpetrators of apartheid because, in the absence of a full acknowledgement of victims of apartheid, there could not be a complete identification of its perpetrators (Lephakga 2015; Mamdani 2002:34; Terreblanche 2002).

It is perhaps important to point out that the above-mentioned shortcomings of the TRC, as noted by Mamdani (2002:33-34), need to be understood against the backdrop of what Cronin (1994:2-8) and Lephakga (2015) term the neo-liberal transition to democracy of the period 1989-1991/1995. This is because, as Lephakga (2015) argues, the period 1989-1995 is fundamental to understanding some of the shortcomings of the TRC. During this period the following events occurred which Lephakga (2015) argues were not accidental or uncalculated: the fall of the Soviet Union (Cronin 1994:2-6); the National Party's (NP) and South African business sector's interest in negotiations with the African National Congress (ANC) (Cronin 1994:2-6; Mkhondo 1993:3-43; Terreblanche 2002:51-124); the elite compromise (Terreblanche 2002:51-124); and the passing of the Promotion of National Unity and Reconciliation Act 3 of 1995 (TRC, Vol. 1, 1998). It is important to note that, during this period, 1989-1995, there was growing opposition to the authoritarian regimes (like the NP in South Africa) in the third world countries (Cronin 1994; Lephakga 2015) and this posed not only a political but also an economic threat to these regimes (Lephakga 2015; Terreblanche 2002). This is because most of these countries had links with and others were in the process of linking up with the Soviet Union (Cronin 1994; Lephakga 2015; Terreblanche 2002). The fall of the Soviet Union therefore presented an opportunity to these authoritarian regimes to retain their grip on the economy of the countries they were governing (Lephakga 2015; Terreblanche 2002). As Fiss (1992:908) points out, 'the fall of the Soviet Union meant that socialism had collapsed and the long historic struggle between capitalism and socialism had come to an end, with capitalism emerging a victor'. It is against this backdrop that Cronin (1994:2-8) and Lephakga (2015) note that the fall of the Soviet Union presented the world - particularly the Third World countries - with one option, namely transition to democracy (Cronin 1994; Lephakga 2015; Terreblanche 2002). But it must be signalled out that the problem was not democracy but the package that it came with, that is democracy under capitalism (Cronin 1994; Lephakga 2015; Terreblanche 2002:16-17). Under this merger of democracy and capitalism nothing changes because we have what Lenin (1917:51) described: 'freedom in capitalist society remains about the same as it was in ancient Greek republics: freedom for slave owners'. On the one hand democracy is based on the equality of rights and privileges maintained and supplied by state power (Terreblanche 2002:16-17), whereas on the other hand capitalism is based on the unequal distribution of property and assets and on the state-guaranteed freedom for everyone to use their assets and property as they please within the prescriptions of the law (Terreblanche 2002:17). It is thus against this backdrop that Lephakga (2015) indicates that the NP's and the business sector's sudden interest in a negotiated settlement was not accidental nor was the sudden passing of the the Promotion of National Unity and Reconciliation Act 34 of 1995 which established the TRC.

It must also be noted that the South African Commission (which became known as the Truth and Reconciliation Commission/TRC) was supposed to be called the Truth Commission of South Africa (Boesak \& DeYoung 2012; Lephakga 2015) following in the footsteps of other commissions which came before it: the truth commission in Uganda in 1974 (Quinn 2003); the National Commission on the Disappeared in Argentina in 1983 (Crenzel 2008); the National Commission for Truth and Reconciliation in Chile in 1991 (Ensalaco 1994); and the Commission of Inquiry in Chad in 1992 (Stevens et al. 2006:296-297; Terreblanche 2002). But during the negotiations (that is, both the informal and formal negotiations - Terreblanche 2002:95), F.W. de Klerk, on behalf of the National Party (NP) (which represented the majority of white people in South Africa Giliomee 2003:487-541) made a request to the commission that his constituency would be more comfortable if it this commission could be named the Truth and Reconciliation Commission of South Africa (TRC). Hence, a biblical or theological concept was included (Boesak \& DeYoung 2012:9). However, it must be pointed out, as Lephakga (2015) and Boesak and DeYoung (2012) noted, that the problem or issue was not reconciliation, but rather the understanding and interpretation of it. This is seen, for instance, with how the Bible was used in South Africa to give theological backing to apartheid which Moodie (1975); Lephakga (2013, 2015); Smith (1979) and Serfontein (1982) point to. Hence Boesak and DeYoung note that, 'from experience in the church as well as politics we knew how the Bible was used in Afrikaner politics, and how the radical message of the Bible was made servant to ideology, domesticated for purposes of subjection and control' (2012:9). Therefore, this article contends that the call for the inclusion of reconciliation to the truth commission was 'not intended to allow reconciliation to confront the country with the demands of the Gospel, but to blunt the progress of radical change and transformation' (Boesak \& DeYoung 2012:9; Lephakga 2015).

Given this background, therefore, this article contends that the Bible, and particularly the story of Zacchaeus, is crucial in illustrating the major shortcomings in South Africa's 
reconciliation project (Boesak 2008; Boesak \& DeYoung 2012). Lephakga (2015) notes that, not only did the addition of the Biblical concept of reconciliation give a religious twist to the South African truth commission process, but an extraordinary move - which Christianised this process - was made when a Christian priest, Archbishop Desmond Tutu, was appointed to chair the commission (Boesak \& DeYoung 2012:63). This move of appointing a priest was extraordinary because all the previous commissions were chaired by lawyers, judges and/or politicians (Boesak \& DeYoung 2012; Crenzel 2008; Ensalaco 1994; Lephakga 2015; Quinn 2003). The chair, as Boesak and DeYoung note, turned the whole process of this commission into a Christian event, 'opening with Christian prayers, praying not to a universal "God of justice" but specifically in the name of Jesus, invoking the "Holy Spirit of God" to guide the proceedings' (2012:63). As a result of the extraordinary move of appointing a Christian priest to chair this commission and his Christianisation of the whole process, many people, particularly Christians, had high expectations (Boesak 2008; Boesak \& DeYoung 2012; Lephakga 2015). This is because Christians know that reconciliation as a biblical concept goes to the roots, in addressing the critical questions of justice, equality, and dignity (Boesak 2008; Boesak \& DeYoung 2012:1; Lephakga 2015). This article therefore contends that once this commission accepted 'reconciliation' as a biblical term it would form part of their foundation (Boesak \& DeYoung 2012; Lephakga 2015) and once they accepted a Christian priest as a chair (Boesak 2008; Boesak \& DeYoung 2012; Lephakga 2015; Terreblanche 2002) - who opened almost all the proceedings of this commission with a prayer - thus invoking the name of Jesus Christ and the Holy Spirit (Boesak \& DeYoung 2012; Lephakga 2015), then this commission should have invited Zacchaeus to come testify (so to speak) - to hear from him what reconciliation meant for him (Boesak 2008; Boesak \& DeYoung 2012; Lephakga 2015).

Against this background this article thus contends that in attempting to move beyond cheap reconciliation towards costly reconciliation which addresses critical questions of justice, equality, and dignity that are so prominent in the biblical understanding of reconciliation, it is necessary to consider, as Boesak (2008:636-654) does, the story of Zacchaeus in Luke 19:1-10. This wonderful, multilayered story has such radical consequences for reconciliation (Boesak 2008; Boesak \& DeYoung 2012; Brown, Fitzmyer \& Murphy 1990; Lephakga 2015). It teaches us (that is South Africans) that reconciliation is radical in that it goes to the roots of injustice(s) and needs to be affected with the community (particularly the wronged community as in this story) in order for it to be genuine (Boesak 2008:636-654). This story also teaches that reconciliation should be transformational - of the life of both the victim and beneficiary and/or perpetrator, of the lifestyle of both, and of the relations between them (though it must be mentioned that the doer must transform their relationship with the community, especially with those they wronged). Finally, this story illustrates that reconciliation is not cheap in that it means the restoration of justice (Boesak 2008:636-654).
It is crucial to note that the story of Zacchaeus, as Adeyemo et al. (2006), Boesak (2008:636-654; Boesak \& DeYoung 2012), Fitzmyer et al. (1990:711) and Brown (1976:222-224) rightly mention, is about the town's rich, infamous tax collector whose wealth had been built through his clever but corrupt manipulation of the tax system and the exploitation of both opportunities and people. It is logical that it might have been the rich who resented him most, but it is the poor that suffered most from his corrupt and ruthless practices as Boesak (2008:636-654; Boesak \& DeYoung 2012) shows. The story also tells us of a man who is aware of his physical impediment and probably knows that he will get no sympathetic, preferential treatment from the crowd and therefore he climbs the tree in the hope of seeing Jesus (Boesak 2008:636654; Boesak \& DeYoung 2012; Brown 1976:222-224; Fitzmyer et al. 1990:711). Jesus stops right at the spot, looks up, the whole crowd fading into fuzzy irrelevance as the focus is entirely on the little man in the sycamore tree, the conversation with Jesus, his conversion, and his reaction (Adeyemo et al. 2006; Brown 1976:222-224; Boesak 2008:636-654; Boesak \& DeYoung 2012; Fitzmyer et al. 1990:711). He draws radical conclusions for his life from his encounter with Jesus and the act of being reconciled with God (Boesak 2008:636-654; Boesak \& DeYoung 2012). He knows this reconciliation needs to be affected by the community in order for it to be genuine (Adeyemo et al. 2006; Boesak 2008). He understands that reconciliation has to be transformational if it is to mean anything: about his life, his lifestyle, and his relationships with the community, especially with those he has wronged. Reconciliation means the restoration of justice, as Boesak (2008:636-654; Boesak \& DeYoung 2012) rightly points out.

Following Zacchaeus's understanding of reconciliation it is thus crucial that reconciliation (1) is affected by the community in order for it to be genuine; (2) has to be transformational if it is to mean anything; and (3) means the restoration of justice, which Zacchaeus sets out to do. Zacchaeus does not spare himself or his possessions (Adeyemo et al. 2006; Boesak 2008:636-654; Boesak \& DeYoung 2012; Brown 1969; Fitzmyer et al. 1990; Lenski 1961). He acknowledges that his wealth was ill-gained and stolen from the sweat of the poor (Boesak 2008:636-654; Boesak \& DeYoung 2012; Brown 1976:222-224; Fitzmyer et al. 1990:711). Boesak points out that for Zacchaeus reconciliation is not cheap: 'Look, half of my possessions Lord, I will give to the poor; and if I have defrauded anyone of anything, I will pay back four times as much' (Lk, 19:8) (Boesak 2008:636-654; Boesak \& DeYoung 2012; Brown 1976:222-224; Fitzmyer et al. 1990:711). Boesak (2008:636-654; Boesak \& DeYoung 2012) further points out that because of Jesus, the incarnation of the reconciliation and compassionate justice of God, Jesus understands how crucial a thing Zacchaeus is doing, Jesus does not enter into some meaningless moralising chat about the relative worth or worthlessness of money, or how just love is enough. Jesus is just as radical, linking Zacchaeus's response immediately to his salvation: 'Today salvation has come to this house...' (Lk. 19:9) (Boesak 2008:636-654; Boesak \& DeYoung 2012; Brown 1976:222-224; Fitzmyer et al. 1990:711). And because there are crucial lessons to be drawn 
from this, the crowd is brought back into the conversation: '... because he too is a son of Abraham' (Lk. 19:9) (Boesak 2008:636-654; Boesak \& DeYoung 2012; Brown 1976:222-224; Fitzmyer et al. 1990:711). It is imperative to note that when Jesus referred to Zacchaeus as also being the son of Abraham, it was to reintegrate him into the community of believers (Boesak 2008:636-654; Boesak \& DeYoung 2012; Brown 1976:222-224; Fitzmyer et al. 1990:711).

This article will conclude that the story of Zacchaues is a good illustration of the shortcomings in the South African reconciliation process. These shortcomings must be understood against the following: 'Zacchaeus stood up and said to the Lord, Listen sir! I will give half [of] my belongings to the poor, and if I have cheated, anyone, I will pay him [or her] back four times as much. Jesus said to him, Salvation has come to this house today, for this man, also, is a descendant of Abraham. The Son of Man came to seek and to save the lost' (Boesak 2008:636-654; Boesak \& DeYoung 2012; Brown 1976:222-224; Fitzmyer et al. 1990:711). The story of Zacchaeus illustrates the cost of reconciliation and as such is important for South Africa's unfinished business of reconciliation (Boesak 2008:636-654; Boesak \& DeYoung 2012). It is against this backdrop that this paper argues that the TRC should have allowed (metaphorically) Zacchaeus to speak, to hear what reconciliation meant for him (Boesak \& DeYoung 2012). This paper will deal with the following subsections in order to point out why the TRC should have allowed Zacchaeus to testify: (1) the importance of the story of Zacchaeus for reconciliation in South Africa; (2) Zacchaeus the epitome of reconciliation; (3) lessons from Zacchaeus for South Africa; and (4) conclusion.

\section{The importance of the story of Zacchaeus for reconciliation in South Africa}

The story of Zacchaeus, the tax collector, is crucial in illustratingthe major shortcomings in South Africa's reconciliation process (Boesak 2008:636; Boesak \& DeYoung 2012:63-66). Unlike the predecessors of the TRC mentioned previously (Crenzel 2008; Ensalaco 1994; Lephakga 2015; Quinn 2003; Stevens et al. 2006), it made an extraordinary move when it deviated from a typical commission that is run by judges, lawyers, and politicians and opted for a Christian priest, Archbishop Desmond Tutu, to run it (Boesak 2008; Boesak \& DeYoung 2012; Lephakga 2015). This extraordinary move should be understood against the commission's mandate which came as a result of the passing of the Promotion of National Unity Act 34 of 1995 (Lephakga 2012; Terreblanche 2002:126; Truth and Reconciliation Commission 1998). This act mandated the commission to promote national unity and reconciliation in a spirit transcending the conflicts and divisions of the past by establishing as complete a picture as possible of the causes, nature, and extent of the gross violations of human rights which were committed during the period 1 March 1960 to 10 May 1994 (Mamdani 1996, 2002; Mamdani in Amadiume and Abdullahi 2000; Lephakga 2015;
Terreblanche 2002:126-127; Truth and Reconciliation Commission 1998). As a result, the commission had a mandate to practise neither impunity nor vengeance (Mamdani 2002:33) and it consequently appointed a Christian priest as its chair (Boesak \& DeYoung 2012:63-64). In its attempt to avoid practising neither impunity nor vengeance, the commission was therefore determined to avoid two pitfalls: on the one hand, reconciliation becoming an unprincipled embrace of political evil; and on the other, a pursuit of justice so relentless as to turn into revenge (Lephakga 2015; Mamdani 2002:33). This extraordinary move was followed by an unprecedented move in the history of these commissions, that of turning the whole process into a decidedly Christian event, opening with Christian prayers (Boesak \& DeYoung 2012:63; Lephakga 2015). Following Boesak and DeYoung (2012:64), this article argues that if this commission invited the Holy Spirit, then it should have also invited Zacchaeus (so to speak) to come to testify, to hear from him what reconciliation means. It is the contention of this article that 'once the name of Jesus (called for forgiveness) is invoked, one cannot then ignore Jesus when one thinks what Jesus is asking (in terms of justice)' (Boesak \& DeYoung 2012:63).

As a result of this extraordinary move, it was expected, especially in Christian circles, that given the commission's determination to practise neither impunity nor vengeance (Mamdani 2002:33), then reconciliation would be allowed to confront the country with the demands of the Gospel (Boesak \& DeYoung 2012; Lephakga 2015). This is because in the biblical understanding of reconciliation, it addresses critical questions of justice, equality, and dignity (Boesak \& DeYoung 2012:1; Lephakga 2015). It is therefore argued that South Africans in general expected more of the process of reconciliation in South Africa (Boesak 2008). Boesak rightly points out that everywhere there are signs of uneasy dissatisfaction among South Africans (Boesak 2008:636-654). This is supported by Desmond Tutu who, years after the commission had done its work, said 'ten years after freedom, but still we are living in squalor while other mostly white, live in palatial homes' (Tutu 1999). Tutu also said: 'I don't know why those people didn't just say, to hell with peace ... to hell with Tutu and the Truth Commission' (Mamphele 2008). Boesak (2008:636-654; Truth and Reconciliation Commission 1998) further observes that 'we know more about the truth that still lies buried than the truth that has been allowed to be heard and F.W. de Klerk's successful court action to block publication of certain documents and his offensive "let-bygones-be-bygones"'. Boesak (2008:636-654) observes that some of the signs of uneasy discontent among South Africans are the result of the TRC's failure to bring to book those who should have taken political responsibility: the political leaders, the generals, big business, or the corporate sector in South Africa. However, it is important to emphasise that the commission's failure to bring some to book is a result of a number of things like its narrow interpretation of its mandate (Lephakga 2015; Terreblanche 2002:127) and its embrace of the analogy of Latin America 
going after dictators which obscured what was distinctive about apartheid in South Africa (Lephakga 2015; Mamdani in Amadiume \& Abdullahi 2000:179; Terreblanche 2002). As a result of the historical and ideological influences of the Latin American commissions (Lephakga 2015; Mamdani in Amadiume \& Abdullahi 2000), the commission dubiously identified victims and perpetrators of the apartheid system (Mamdani 2002:33-34; Terreblanche 2002:124-127). Consequently it narrowly interpreted its mandate and wrote the vast majority of apartheid victims, particularly victims of systematic exploitation, out of its version of history (Mamdani in Amadiume \& Abdullahi 2000:183).

Mamdani (in Amadiume \& Adbullahi 2000:183) notes that the unintended outcome of the narrow interpretation of its mandate and the Latin American understanding of human rights violations, which obscured what was distinctive about apartheid, has been to drive a wedge between the beneficiaries and victims of apartheid. The commission was consequently not able to apply the judgement of the international human rights community that 'apartheid was a crime against humanity' to racial capitalism and the business sector's involvement in it (Lephakga 2015; Terreblanche 2002:130-131). Terreblanche (2002:131) notes that the TRC lost a golden opportunity to educate the individual and corporate beneficiaries of apartheid about their direct responsibilities for the disrupted social structures and abject poverty of the majority of blacks. He further notes that 'if the beneficiaries had been educated about their participation in racial capitalism, they would certainly have been less arrogant, and possibly more compassionate and generous' (Lephakga 2015; Terreblanche 2002:131). Boesak (2008:636-654) rightly points out that there is deep anger at the government's inability to bring some dignity to the process of compensation for victims and at the fact that too many got away with it because of the obscuring of what was distinctive about apartheid, that is, that apartheid was aimed less at individuals than at entire communities and entire population groups (Mamdani in Amadiume \& Adbullahi 2000:183). Thus the story of Zacchaeus can be used to demonstrate and call for reconciliation in society that is radical, that goes to the roots. Boesak and DeYoung (2012:1) rightly note that 'we believe unless we remove injustice at the roots, the weeds of alienation and fragmentation will return and choke the hope for reconciliation'. This is because the powerful in South Africa often use reconciliation to merely reach some political accommodation. And this political accommodation favours the rich and powerful, and deprives the powerless of justice and dignity (Boesak \& DeYoung 2012:1). It does not end here as this reconciliation is often presented as if it does respond to the needs for genuine reconciliation and uses language that sounds like the truth but is, in fact, deceitful (Boesak \& DeYoung 2012:1). Boesak and DeYoung (2012:1) note that Christians measure these matters with the yardstick of the Gospel and therefore know better. But when we discover that what is happening is in fact not reconciliation, and yet for reasons of self-protection, fear, or desire for acceptance by the powers that be, seek to accommodate this situation, justify it, refuse to run the risk of challenge and prophetic truth telling, we become complicit in deceitful reconciliation and we deny the demands of the Gospel and refuse solidarity with the powerless and oppressed (Boesak \& DeYoung 2012:1). Thus the story of Zacchaeus is crucial for the process of true reconciliation in South Africa.

\section{Zacchaeus the epitome of reconciliation}

Zacchaeus the tax collector is regarded as the epitome of reconciliation because in the story of Zacchaeus as outlined in the Gospel of Luke, he is shown to understand and demonstrate how his manipulation of the tax system and the exploitation of the poor have earned him the reputation of being a sinner and corrupt tax collector, and thus cutt him off from the covenant between God and his people (Boesak 2008:636-654; Boesak \& DeYoung 2012:63-73; Brown 1976:222-224; Fitzmyer et al. 1990:711). It is important at this stage to point out that Zacchaeus acknowledged his wrongs and also understood the consequences of his actions for himself and those he wronged (Brown 1976:222-224; Fitzmyer et al. 1990:711). As a result of his reputation it is understandable that the people hated tax collectors (Boesak \& DeYoung 2012:63-66; Brown 1976:222-224; Fitzmyer et al. 1990:711). They were the symbol of the oppression they met every day (Boesak 2008:636-654; Boesak \& DeYoung 2012:6373; Brown 1976:222-224; Fitzmyer et al. 1990:711). They were the face of the oppressor in Rome or of the governor in Jerusalem. If they were Jews, and they worked for Rome, the betrayal was enormous (Boesak 2008:636-654; Boesak \& DeYoung 2012:63-73; Brown 1976:222-224; Fitzmyer et al. 1990:711). On the one hand Zacchaeus as a Jew participated in the oppression of the Jewish people (Brown 1976:222-224; Fitzmyer et al. 1990:711), that is his people, and on the other hand Zacchaeus as a tax collector participated in a system which exploited the poor through collection of taxes (Brown 1976:222-224; Fitzmyer et al. 1990:711), among other things, to sustain the lavish lifestyle of emperors, their governors, and the corrupt tax collectors (Boesak 2008; Boesak \& DeYoung 2012; Brown 1976:222-224; Fitzmyer et al. 1990:711). Zacchaeus also participated in a system which used the Jewish people's money to fund the building of temples in honour of emperors in a holy land (Boesak \& DeYoung 2012:64-66).

It is, however, crucial to note that as a result of Zacchaeus's willingness to see Jesus, the radical reconciler on the one hand demonstrated (through his willingness to change) how reconciliation needs to be affected (by) with the community in order for it to be genuine (Boesak 2008:636-654; Brown 1976:222-224; Fitzmyer et al. 1990:711). Zacchaeus shows us how reconciliation has to be transformational if it is to mean anything (transformational - of his life, of his lifestyle, and of his relationships with the community and especially with those he has wronged) (Boesak 2008:636-654; Brown 1976:222-224; Fitzmyer et al. 1990:711; Lenski 1961). The story of Zacchaeus also demonstrates how reconciliation means 
the restoration of justice. Zacchaeus acknowledged that his wealth was ill-gained, stolen from the poor, and that reconciliation is not cheap: 'Look, half of my possessions, Lord, I will give to the poor; and if I have defrauded anyone of anything, I will pay back four times as much' (Lk. 19:8) (Boesak 2008:636-654; Boesak \& DeYoung 2012:63-73; Brown 1976:222-224; Fitzmyer et al. 1990:711; Lenski 1961). But on the other hand, Jesus (the radical reconciler), the incarnation of reconciliation and compassionate justice of God, understands how crucial a thing Zacchaeus is doing. Jesus links Zacchaeus's response to his salvation: 'Today salvation has come to this house' (Lk. 19:9) (Boesak 2008:636-654). It is against this background that Zacchaeus is referred to as an epitome of reconciliation and the coming of the day of Salvation, that is being restored to the community of believers (Brown 1976:222-224; Fitzmyer et al. 1990:711; Lenski 1961).

Also of note is that, the story of Zacchaeus begins with an explanation, namely that Jesus went through Jericho, which epitomises colonisation and occupation by the Romans (Brown 1976:222-224; Fitzmyer et al. 1990:711; Lenski 1961:937). This is mentioned here to underline that Jesus as a radical reconciler was a subject of Rome: colonised, occupied, and yet to be crucified, and as such his preaching and teaching must be understood against this background as a protest against the imperial domination and a calling for the reign of the God of justice (Boesak 2008:636-654; Boesak \& DeYoung 2012:63-73). The story then mentions that there was a chief tax collector there named Zacchaeus, who was rich, again reminding us that Zacchaeus as a Jew participated in a system which both exploited his own people and sustained the lavish lifestyle of emperors, governors, and tax collectors and the building of lavish buildings in honor of emperors, on holy soil (Adeyemo et al. 2006; Boesak 2008:636-654; Boesak \& DeYoung 2012:63-73). Boesak and DeYoung point out that in the Gospel Zacchaeus has in many ways, come to epitomise the image of the 'tax collector and sinner'. As such, it is no wonder he could not find a place among the crowds who waited for Jesus that day (Adeyemo et al. 2006). This story goes on to describe his willingness to see Jesus (the radical reconciler), but he was a little man and could not see Jesus because of the crowd (Adeyemo et al. 2006). Thus it was not just because he was a man of small stature. The people knew him. He knew he would not be welcomed by them (Boesak \& DeYoung 2012:66). This re-emphasises that as a result of his being a Jew and working for Rome, which oppressed them, the betrayal was enormous. Zacchaeus knew that he would not get sympathetic, preferential treatment from the crowd (Boesak 2008:636-654; Boesak \& DeYoung 2012:63-73; Lenski 1961).

Zacchaeus not only acknowledged that his wealth was illgained, stolen from the sweat of the poor (Adeyemo et al. 2006), but also knew that as a Jew he participated in a scandal which made him the symbol of their oppression and that people felt betrayed (Boesak 2008:636-654). It is also crucial to recall that Zacchaeus (whose name meant 'pure' or 'innocent') as a Jew was regarded as unclean because of his continual contact with Gentiles (Brown 1969; Fitzmyer et al.
1990) and because his job required him to work even on the Sabbath, which was against Jewish law (Boesak 2008:636654; Boesak \& DeYoung 2012:63-73; Brown 1969; Lenski 1961). That is why the rabbis taught that observant Jews should not eat with such people and why they spoke of tax collectors and sinners in one breath (Adeyemo et al. 2006; Fitzmyer et al. 1990). Why would anyone give up their place in the crowd, and their chance to see Jesus, for someone like Zacchaeus? Among the crowd, the hostility would have been palpable and perhaps physical. As a result, the tree (i.e. the sycamore tree) was the safest spot for him (Boesak \& DeYoung 2012:63-73). But the tree was also a symbol of his complete isolation, especially amongst the poor and oppressed, those extorted by men like him every day of their lives (Adeyemo et al. 2006; Boesak 2008:636-654). His participation in the scandalous tax system not only made him an enemy of the Jewish people (i.e. his community) but it also excluded him from being part of the covenant (Adeyemo et al. 2006; Boesak 2008:636-654; Boesak \& DeYoung 2012:63-73; Brown 1969; Lenski 1961; Fitzmyer et al. 1990).

It is also crucial to note, as Boesak rightly points out, that following Zacchaeus's knowledge and understanding of what his participation in the exploitative system of tax collection meant, and that he would not get sympathetic, preferential, treatment from the crowd, he went and climbed the tree in the hope of seeing Jesus (Boesak 2008:636-654; Boesak \& DeYoung 2012:63-73). This is mentioned here to underline Zacchaeus's willingness to face anything to see Jesus, the radical reconciler (Adeyemo et al. 2006; Boesak \& DeYoung 2012:63-73; Brown 1969). Zacchaeus went anyway, apparently willing to face whatever might happen (Adeyemo et al. 2006). That is astonishing enough. But it becomes even more so when Jesus stopped underneath that sycamore tree and looked up (Adeyemo et al. 2006; Brown 1969). This is crucial, because this story speaks of salvation (Boesak 2008). When Jesus saw Zacchaeus's willingness to see him (i.e. Jesus the radical reconciler) despite everything, he decided to stop under the sycamore tree (the act alone of climbing the tree having isolated Zacchaeus) (Adeyemo et al. 2006; Lenski 1961) and as a result the whole crowd faded into uncertain irrelevance as the focus is entirely on the little man in the tree (Adeyemo et al. 2006; Fitzmyer et al. 1990), the conversation with Jesus, and his conversion and reaction (Boesak 2008:636654). Zacchaeus understood that he was alienated not only from his community, but also from God (Adeyemo et al. 2006; Brown 1969; Lenski 1961). Through his life of exploitation and self-enrichment, he had robbed the poor of their money and their dignity (Boesak \& DeYoung 2012:63-73) and he had also broken the bonds of solidarity and exploited his people's fear of the Roman occupier by his extortion (Brown 1969). He knew they had no choice but to come through those gates where he lay in wait. He knew that even if he charged them double, there was no appeal possible, nothing they could do to stop him. He could do what he wanted: they were helpless and their helplessness was his power (Boesak 2002:67).

Following his willingness to see Jesus, the radical reconciler and his acknowledgement that his wealth was ill-gained, 
Zacchaeus, without waiting for Jesus to tell him what to do, came forward and declared his understanding that reconciliation is not cheap and offered: 'Look half of my possessions, Lord, I will give to the poor' (Lk. 19:8) (Adeyemo et al. 2006; Boesak 2008; Boesak \& DeYoung 2012). This stresses Zacchaeus's seriousness; he gives half of his wealth, not on a percentage basis, not over a period of time, nor does he pledge that he will do so come next harvest time but here and now (Adeyemo et al. 2006; Boesak 2008:636-654; Boesak \& DeYoung 2012:63-73). Zacchaeus adds: 'And if I have defrauded anyone, I will pay back four times as much' (possibly out of the other half he will be left with after giving half of his possession to the poor) (Lk. 19:8) (Adeyemo et al. 2006; Boesak 2008; Brown 1969; Lenski 1961). This act by Zacchaeus is not generosity, and certainly it is not charity; it is Zacchaeus's desire to do justice (Boesak \& DeYoung 2012:67). It is also crucial at this stage to dispel the argument that Zacchaeus decided to give this money because he was a rich man. Even if one is rich, giving away half of one's wealth and repaying people four times what one has robbed of them, still amounts to a great deal of money (Boesak 2008:636-654; Boesak \& DeYoung 2012:63-73). It should also be recalled that there was a whole city that needed to be compensated for what Zacchaeus had done over many years (Adeyemo et al. 2006; Fitzmyer et al. 1990). This act shows his understanding and acknowledgement that not only is reconciliation not cheap but also that it needs to be affected with the community in order for it to be genuine, and that reconciliation needs to be transformational if it is to mean anything, namely the restoration of justice (Adeyemo et al. 2006; Boesak 2008:636-654).

Zacchaeus's act of giving up half (and probably more) of his wealth is more than just about the money (Adeyemo et al. 2006). The manner and spirit in which Zacchaeus did the act of giving back some of his wealth is different and radical (Boesak \& DeYoung 2012:63-73). This claim is based on the fact that in reality Zacchaeus was offering to give up his status as one of the richest men in Jericho in order to make restitution, to make right what he did wrong (Adeyemo et al. 2006), in order to restore his relationship with both his neighbours and God (Adeyemo et al. 2006; Boesak \& DeYoung 2012:67). It is also imperative to note that Zacchaeus does not shift the blame by saying that he will order his subcontractors to make a contribution to his payment because they also benefitted from the exploitative system of tax collection (Adeyemo et al. 2006; Brown 1969; Fitzmyer et al. 1990; Lenski 1961). He takes responsibility himself for the wrongs he did and for what he must do to undo those wrongs. This is important because it demonstrates how reconciliation presupposes justice within it (Boesak 2008:636-654; Boesak \& DeYoung 2012:63-73; Lephakga 2015). As Boesak rightly points out, reconciliation which goes to the roots of injustice, acknowledges that reconciliation must be affected with the community and that it needs to be transformational, that is, it needs to transform the life of both the beneficiary and/or perpetrator and victim, the lifestyle of both the beneficiary and/or perpetrator and victim, and the relationship of a beneficiary with the community, particularly with those a beneficiary and/or perpetrator has wronged (Boesak 2008:636-654).

\section{Lessons from Zacchaeus for South Africa}

At this stage we will identify and elaborate on at least 10 lessons about reconciliation from the story of Zacchaeus as pointed out by Boesak and DeYoung (2012).

1. Firstly, we must note that reconciliation cannot be shallow, that it is not about covering up the evil or simply papering over the cracks (Boesak 2008:636-654; Boesak \& DeYoung 2012:63-73). It is for this reason that Lephakga (2015) argues that the TRC was a final seal on the elite compromise, because the Commission was used to ratify the elite compromise that was reached at both the informal and formal negotiations. This claim is based on the inability or unwillingness of the TRC to uncover the truth about systematic exploitation or how it uncovered some truth about one form of victimisation under apartheid while ignoring another form of victimisation (Terreblanche 2002:124-125). In addition, it obscured what was distinctive about apartheid (Mamdani in Amadiume \& Abdullahi 2002:179) and thus absolved the business sector of South Africa (Terreblanche 2002:124-132), which resulted in the vast majority of apartheid being written out of the Commission's version of history (Mamdani in Amadiume \& Abdullahi 2002:183). The story of Zacchaeus shows that reconciliation is not about covering up the evil or simply papering over the cracks (Adeyemo et al. 2006; Boesak 2008:636-654; Boesak \& DeYoung 2012:63-73). In the story of Zacchaeus, he acknowledges what he has done wrong: I stole, I exploited, I cheated, I betrayed ('Listen, sir! I will give half my belongings to the poor. And If I have defrauded anyone of anything, I will pay back four times as much' [Lk. 19:8]) (Boesak 2008:636-654; Boesak \& DeYoung 2012:63-73). This is important because Zacchaeus did not try to make excuses for himself, blaming the system against which he was helpless. He did not try to defend himself by arguing that he simply had to make a living, that this was merely a job, or that he had a family to look after. He knew that he had benefitted unjustly from oppression and suffering. Boesak and DeYoung (2012:67-68) rightly point out that that is self-justification, and Zacchaeus knows that self-justification always stands in the way of true reconciliation: it mocks the wronged, nullifies repentance, and trivialises forgiveness.

2. Secondly, the story of Zacchaeus points out that reconciliation is not possible without remorse (Adeyemo et al. 2006; Boesak 2008; Boesak \& DeYoung 2012; Brown 1969; Lenski 1961). This is because a sincere remorse in a form of an apology, for instance, lays the groundwork for the possibility of forgiveness (Gobodo-Madikizela 2002:8). Hence Gobodo-Madikizela argue that '...genuine remorse humanizes perpetrators and transforms their evil from the unforgivable into something that can be 
forgiven' (2002:8). Accordingly, the story of Zacchaeus demonstrates that remorse is not about a lot of words, wringing hands and saying 'sorry' just to get it over and done with as quickly as possible (Adeyemo et al. 2006; Boesak 2008:636-654; Boesak \& DeYoung 2012:63-73; Lenski 1961). This story also teaches that the victim has a right to restitution - and it has nothing to do with one's magnanimity, it is all about justice (Adeyemo et al. 2006; Boesak 2008; Boesak \& DeYoung 2012; Brown 1969; Lenski 1961). Remorse is also about acknowledging the victim's pain as a result of one's action and making it right with acts of justice (Villa-Vicencio et al. 2006). 'And if I have defrauded anyone, I will pay back four times as much' (Lk. 19:8): that is what 'I am sorry' means (Adeyemo et al. 2006; Boesak 2008; Boesak \& DeYoung 2012; Brown 1969; Lenski 1961).

3. The third lesson from the story of Zacchaeus is that he knows that reconciliation is not cheap (Lephakga 2015), not just in a spiritual sense but literally (Adeyemo et al. 2006; Boesak \& DeYoung 2012:68). This is because on the one hand reconciliation goes beyond its simplistic understanding and/or interpretation (Lephakga 2015; Mamdani 1996) and on the other hand it presupposes justice (Lephakga 2015). It is for this reason that the authors of the Kairos Documents cautioned South Africa that reconciliation without justice would lead to cheap reconciliation - a concept borrowed from the German theologian Dietrich Bonhoeffer (1906-1945) (Lephakga 2015; Shore 2009:136-137). Therefore, having acknowledged that his wealth was ill-gained and stolen from the poor, Zacchaeus demonstrates that reconciliation is not cheap by saying 'Look, half of my possessions Lord, I will give to the poor; and If I have defrauded anyone of anything, I will pay back four times as much' (Lk. 19:8) (Adeyemo et al. 2006; Boesak 2008; Boesak \& DeYoung 2012; Brown 1969; Lenski 1961). Thus, Boesak and DeYoung rightly point out that Zacchaeus's theft from the poor was not spiritual; it was real and tangible. His wealth was undeserved just as the impoverishment of the poor was undeserved, and Zacchaeus knew that (Adeyemo et al. 2006; Boesak 2008; Boesak \& DeYoung 2012; Brown 1969; Lenski 1961). As a result he not only gives away half of his possessions but he repays four times those he defrauded. Zacchaeus did this because he understood that through his participation in the exploitative tax system, inequality was created between the poor and the rich (Boesak 2008:636-654; Boesak \& DeYoung 2012:63-73).

4. It is thus imperative to link the third lesson (that reconciliation is not cheap) and the fourth lesson because there can never be reconciliation without equality (Boesak 2008:636-654; Boesak \& DeYoung 2012:63-73; VillaVicencio et al. 2006). Hence Pietersen argues that, 'reconciliation in South Africa will remain a pipe dream if economic equality is not achieved' (Pietersen 2011). Thus Zacchaeus understood that there can be no reconciliation without equality. He understood that exploitation created inequality in society and demonstrated this when he said: 'Look, half of my possessions Lord, I will give to the poor; and if I have defrauded anyone of anything, I will pay back four times as much' (Lk. 19:8) (Boesak 2008:636-654; Boesak \& DeYoung 2012:63-73). Boesak and DeYoung are correct in noting that all along Zacchaeus's wealth and his connections with Rome and the powerful had placed him above his people. He had participated in and benefitted from, a political, economic, and social system that created and maintained profound inequalities in his society (Adeyemo et al. 2006; Boesak 2008; Boesak \& DeYoung 2012; Brown 1969; Lenski 1961). Roman imperial society was unthinkable without the hierarchies built on class, power, and privilege, and the arrogance and entitlement that went with it (Boesak \& DeYoung 2012:63-73).

5. The fifth lesson from the story of Zacchaeus is that reconciliation is not just about restoring our broken relationship with God, but also restoring our relationships with the community (Adeyemo et al. 2006; Boesak 2008:636-654; Boesak \& DeYoung 2012; Brown 1969; Lenski 1961). Boesak and DeYoung rightly point out that in the story of Zacchaeus the people did not consider that the broken relationship (between themselves as a community and Zacchaeus) was restored with the conversation between Jesus and Zacchaeus and with Jesus' announcement of his acceptance of Zacchaeus by going to his house. It was restored with his showing remorse and conversion by doing justice (Boesak 2008:636-654; Boesak \& DeYoung 2012:63-73).

6. The sixth lesson from the story of Zacchaeus is that he has sinned against God and against his neighbours, and that he had to make public recompense (Boesak 2008:636-654; Boesak \& DeYoung 2012:63-73). He does not try to hide behind the 'this is between me and my God' cop-out (Boesak \& DeYoung 2012:70). The rich rewards from his life of extortion for him and his family were public rewards: favour with the Romans (Adeyemo et al. 2006; Boesak 2008; Boesak \& DeYoung 2012; Brown 1969; Lenski 1961), connections with the elite and the enjoyment of the patronage system, social and political privilege, opulence and comfort, and a worry-free life (Boesak 2008:636-654; Boesak \& DeYoung 2012:63-73). The suffering of his victims was a public suffering. His remorse had to be public as well, and so should be the restoration of his broken relationship with his community (Boesak \& DeYoung 2012:70).

7. The seventh lesson from the story of Zacchaeus is that when reconciliation means uncovering the sin, showing remorse, making restitution, and restoring relationships with deeds of compassionate justice, then and only then is reconciliation complete, right, sustainable, and radical, because it becomes transformational (Boesak 2008:636654; Boesak \& DeYoung 2012:63-73). When reconciliation has integrity it restores human integrity, and that is where salvific power is (Villa-Vicencio et al. 2006). This is because biblical and radical reconciliation wants to bring us to the point where we learn to live not just with the other because we have no choice - but for the other - because 
that is our choice - where the peace among us is not just the absence of violence, but the active presence of justice (Boesak \& DeYoung 2012:70).

8. The eighth lesson from Zacchaeus' story as pointed out by Boesak and DeYoung is that when genuine reconciliation takes place, it brings more than just individual salvation. It brings salvation for Zacchaeus and his house (household) (Boesak 2008:636-654; Boesak \& DeYoung 2012:63-73). As a result of this salvation, there is wholeness to his restoration (Boesak 2008:636-654; Boesak \& DeYoung 2012:63-73). This is because Zacchaeus and his whole house had benefitted from his life of exploitation (and his whole house had been cursed by the people who saw their opulent lifestyle built upon the impoverishment of the peasants) (Adeyemo et al. 2006; Boesak 2008:636-654; Boesak \& DeYoung 2012:63-73). But through genuine reconciliation, that whole generation was restored to wholeness and community with others and with God (Boesak 2008:636-654; Boesak \& DeYoung 2012:63-73).

9. The nineth lesson is that, in being restored, Zacchaeus switched sides. It was impossible after such a public display of shame and such a public conversion for him to go back to doing what he had done all his life: tax collecting, robbing, cheating, exploiting, living the life of the idle rich so vividly described by Isaiah (Boesak 2008:636-654; Boesak \& DeYoung 2012:63-73). His confrontation with Jesus was also a confrontation with his own life and with the choices he had made. From that moment on, nothing could be the same for Zacchaeus (Boesak 2008:636-654; Boesak \& DeYoung 2012:63-73). It is also crucial to note that following Zacchaeus's conversion, he could no longer work for the Romans; his political allegiances changed once his spiritual allegiance changed (Boesak 2008:636-654; Boesak \& DeYoung 2012:63-73).

10. The 10th and final lesson from the story is that Zacchaeus has moved from being known as a tax collector to being a Son of Abraham; that is part of the covenant (Adeyemo et al. 2006; Boesak 2008; Boesak \& DeYoung 2012; Brown 1969; Lenski 1961). Up to this point Zacchaeus was known as 'the tax collector', a man who had estranged himself from his own people, and a traitor who had sold his soul to Rome for money. He ingratiated himself with the Romans, the occupying force of colonialist oppression, but found no place among his own people (Boesak 2008:636-654; Boesak \& DeYoung 2012:63-73).

\section{Conclusion}

This article contended that the TRC should have invited Zacchaeus to testify (so to speak) and to hear from him what reconciliation meant for him as his story is a good illustration of the shortcomings in the South African reconciliation process. This is because the TRC did not take the Gospel seriously, despite the Christianisation of the TRC process, namely (1) the addition of the Christian (and the Gospel) concept of reconciliation within this commission; (2) the appointment of a Christian priest (i.e. Archbishop
Desmond Tutu) as the Commission's chair and (3) the opening of its sessions with prayer and the invitation of Jesus and the Holy Spirit. This paper has demonstrated that the Commission missed the opportunity to understand the following about reconciliation as shown in the story of Zacchaeus: (1) that reconciliation needs to be affected with the community in order for it to be genuine; (2) that reconciliation has to be transformational if it is to mean anything (transformational of the life of both the beneficiary and/or perpetrator and victim, the lifestyle of both the beneficiary/perpetrator and victim, the relationship between the beneficiary/perpetrator and the community, especially those that were wronged); and (3) that reconciliation means the restoration of justice. It has also been shown that the shortcomings of the TRC must be understood against the following: 'Zacchaeus stood up and said to the Lord, Listen sir! I will give half [of] my belongings to the poor, and if I have cheated, anyone, I will pay him [or her] back four times as much. Jesus said to him, Salvation has come to this house today, for this man, also, is a descendant of Abraham. The Son of Man came to seek and to save the lost' (Lk. 19:1-10). This is because the story of Zacchaeus demonstrates the cost of reconciliation and as such is important for South Africa's unfinished business of reconciliation. Given the Christianisation of the whole process of this commission, it is crucial to emphasise that the TRC should have taken the Gospel as seriously in its proceedings and its consequences as it did at the formal opening of each session. Once the commission opened the doors to invite in Jesus and the Holy Spirit, they should have called Zacchaeus to testify, so to speak, to hear from him what reconciliation meant for him.

\section{Acknowledgements Competing interests}

The author declares that he has no financial or personal relationships which may have inappropriately influenced him in writing this article.

\section{References}

Adeyemo, T., (ed.), 2006, Africa Bible Commentary, Worldlive Publishers, Nairobi, Kenya.

Amadiume, I. \& Abdullahi, A. (eds.), 2000, The politics of memory: Truth, healing and social justice, Zed Books, London.

Boesak, A., 1977, Farewell to innocence: A socio-ethical study on Black theology and Black power, Orbis Books, Maryknoll.

Boesak, A., 2008, 'And Zacchaeus remained in the tree: Reconciliation and justice and the Truth and Reconciliation Commission', Verbum et Ecclesia 28(3), 636-654.

Boesak, A. \& DeYoung, C.P., 2012, Radical reconciliation: Beyond political pietism and Christian quietism, Orbis Books, Maryknoll, NY.

Brown, D., 1976, The Four Gospels: A Commentary, critical, experimental and practical, The Banner of Truth Trust, Edinburgh, Scotland.

Crenzel, E., 2008, 'Argentina's Commission on the disappearance of persons: Contributions to transitional justice', The International Journal of Transitional Justice 2, 173-191. http://dx.doi.org/10.1093/ijtj/ijn007

Cronin, J., 1994, 'Sell-out, or the culminating moment?: Trying to make sense of the transition', History Workshop at the University of Witwatersrand, 13-17th July, Africana Library, University of the Witwatersrand, 1-39 (http://hdl.handle.net/ 10539/7766)

Ensalaco, M., 1994, 'Truth commissions for Chile and El Salvador: A report and assessment', Human Rights Quarterly 16(4), 656-675. http://dx.doi.org/10.2307/ 762563

Fiss, O.M., 1992, 'Capitalism and democracy', Michigan Journal of International Law 13(4), 908-920. 
Fitzmyer, J.A., Brown, R.E., \& Murphy, R.E. (eds.), 1990, The New Jerome Biblical Commentary. Prentice Hall, Englewood Cliffs, NJ.

Giliomee, H., 2003, The Afrikaners: Biography of a people, Tafelberg Publishers, Cape Town.

Gobodo-Madikizela, P., 2002, 'Remorse, forgiveness, and rehumanization: Storie from South Africa', Journal of Humanistic Psychology 42(1), 7-32. http://dx.doi. org/10.1177/0022167802421002

Lenin, V.I., 1917, The state and revolution, International Publishers, New York.

Lenski, R.C.H., 1961, The interpretation of St. Luke's Gospel, Augsburg Publishing House, Minneapolis, MN.

Lephakga, T., 2012, 'Reclaiming God and reclaiming dignity: The history and future of black liberation from internalized oppression', Studia Historiae Ecclesiasticae $38(2), 65-80$.

Lephakga, T., 2013, 'The history of theologized politics in South Africa, the 1913 Land Act and its impact on the flight from the black self', Studia Historiae Ecclesiasticae 39(2), 379-400.

Lephakga, T., 2015, 'Dealing lightly with the wounds of my people: A theological ethical critique of the South African Truth and Reconciliation Commission', Unpublished PhD thesis, University of South Africa, Pretoria.

Mamdani, M., 1996, 'Reconciliation without Justice', South African Review of Books $46,3-5$.

Mamdani, M., 2002, 'Amnesty or impunity?: A critique of the report of the Truth and [Reconciliation] Commission of South Africa (TRC)', Diacritics 32(3/4), 32-59. http://dx.doi.org/10.1353/dia.2005.0005
Mkhondo, R., 1993, Reporting South Africa, David Philip Publishers, Cape Town.

Moodie, T.D., 1975, The rise of Afrikanerdom: Power, apartheid, and the Afrikaner civil religion, University of California Press, London.

Pietersen, M., 2011, Reconciliation a pipe dream without equality: Study, viewed 13 November 2015 from http://www.iol.co.za/dailynews/news/reconciliation-apipe-dream-without-equality-study-1.1194718\#.VkRr2r8pp2A

Quinn, J.R., 2003, The Politics of acknowledgment: An analysis of Uganda's Truth Commission, McMaster University, Hamilton, Canada.

Serfontein, J.H.P., 1982, Apartheid change and the NG Kerk, Taurus, Emmarentia, South Africa.

Shore, M., 2009, Religion and conflict resolution: Christianity and South Africa's Truth and Reconciliaton Commission, Ashgate Publishing Limited, Farnham, England.

Smith, H.L., 1979, Anatomy of apartheid. Khanya Publishers, Germiston.

Stevens, G., Franchi, V. \& Swart, T. (eds.), 2006, A race against time: Psychology and challenges to deracialisation in South Africa, UNISA Press, Pretoria.

Terreblanche, S., 2002, A history of inequality in South Africa: 1652-2002, University of Natal Press, Pietermaritzburg.

Truth and Reconciliation Commission, 1998, Truth and Reconciliation Commission of South Africa, final report (5 vols.), Juta, Cape Town.

Tutu, D., 1999, No future without forgiveness, Rider Books, Johannesburg.

Villa-Vicencio, C. \& Du Toit, F., 2006, Truth and reconciliation in South Africa: 10 years on, New Africa Books, Cape Town. 